\title{
ANALISIS PREFERENSI KONSUMEN TERHADAP KARAKTERISTIK ORGANOLEPTIK PRODUK ROTI MANIS DI KOTA MALANG
}

\section{Consumer Preference Analysis on Organoleptic Properties of Sweet Bun Product in Malang City}

\author{
Jaya Mahar Maligan, Bayu Mas Amana, Widya Dwi Rukmi Putri \\ Jurusan Teknologi Hasil Pertanian, FTP Universitas Brawijaya Malang \\ Jl. Veteran, Malang 65145 \\ *Penulis Korespondensi, Email: maharajay@gmail.com
}

\begin{abstract}
ABSTRAK
Penelitian ini bertujuan untuk menganalisis preferensi konsumen terhadap karakteristik organoleptik (meliputi atribut warna, rasa, aroma, tekstur dan kenampakan) produk roti manis (10 merek) yang dijual di Kota Malang, menggunakan uji hedonik dan uji rangking. Hasil penelitian menunjukkan bahwa atribut warna MYB berbeda nyata dengan HLB, sebaliknya HLB tidak berbeda nyata dengan DFL. Atribut aroma SNT berbeda nyata dengan HLB, sedangkan HLB tidak berbeda nyata dengan MYB. Atribut kenampakan MYB berbeda nyata dengan sampel yang lain, dan sebaliknya HLB tidak berbeda nyata dengan DFL. Untuk atribut rasa, SHB tidak berbeda nyata dengan NYB, namun berbeda nyata dengan MYB. Atribut tekstur dari SHB tidak berbeda nyata dengan NYB, namun berbeda nyata dengan DFL. Pada uji ranking sampel HLB berada di peringkat 1 untuk keseluruhan atribut dan sampel NYW di peringkat 10 untuk total nilai keseluruhan.
\end{abstract}

Kata Kunci : Preferensi konsumen, Roti manis, Karakteristik organoleptik

\section{ABSTRACT}

The purpose of this research was to analyze consumer preferences for organoleptic characteristics (including color, taste, aroma, texture and appearance) sweet bun products (10 brands) which is sold in Malang City, using hedonic and rank tests. The results showed that MYB color attributes was significantly different from HLB, whereas HLB was not significantly different from DFL. The SNT aroma attribute was significantly different from HLB, whereas $H L B$ was not significantly different from MYB. The appearance attributes of MYB was significantly different from other samples, and vice versa HLB was not significantly different from DFL. For taste attributes, SHB was not significantly different from NYB, but was significantly different from MYB. The texture attributes of SHB was not significantly different from NYB, but was significantly different from DFL. The result of ranking test showed that HLB in the first position in the overall attributes and the NYB sample was the last position for the total overall score.

Keywords: Preferences, Consumers, Sweet Bun, Organoleptic Characteristics

\section{PENDAHULUAN}

Perkembangan ilmu pengetahuan dan teknologi di Indonesia sedikit banyak memberikan dampak dalam kemajuan di berbagai sektor. Salah satu sektor penting yang saat ini menjadi target pasar Indonesia terdapat dalam usaha kecil dan mikro yang bergerak di bidang pangan. Berdasarkan data dari Badan Pusat Statistik (BPS) Republik Indonesia, sampai dengan tahun 2015 jumlah usaha kecil dan usaha mikro yang bergerak di bidang makanan terutama bakery mengalami peningkatan dan penurunan. Jumlah usaha mikro pada tahun 2012 - 2015 mengalami peningkatan signifikan yakni $871.898-1.473 .205$ usaha mikro 
yang bergerak di bidang makanan. Sementara untuk usaha kecil, mengalami fluktuasi dengan jumlah lebih dari 20.000 pengusaha. Hal ini menunjukkan jika produk bakery masih menjadi favorit masyarakat yang bergerak di bidang usaha mikro untuk bersaing dengan pasar global.

Program pembangunan industri dan perdagangan di Jawa Timur memang diarahkan untuk mendorong pertumbuhan Usaha Kecil Menengah di tingkat masyarakat maupun pengusaha (Disperindag Provinsi Jawa Timur, 2017). Dengan banyaknya Perguruan Tinggi, Sekolah Menengah dan Instansi Pemerintah yang mengatur produsen tentang seberapa banyak mereka mencapai target dan menentukan pasar lokal mereka. Keberadaan toko roti modern yang menyebabkan persaingan tidak sempurna didalam mencapai target masing masing toko, yang menyebabkan banyak toko roti kecil menjadi kalah branding dengan produk yang dapat dikatakan tidak terlalu jauh dalam segi rasa dan kualitas. Berdasarkan hasil survey pendahuluan di tahun 2016 terdapat 42 toko bakery di Kota Malang yang tersebar luas di 5 Kecamatan dengan range outlet dan harga yang beragam.

Penelitian ini bertujuan untuk menganalisis preferensi konsumen terhadap karakteristik organoleptik (meliputi atribut warna, rasa, aroma, tekstur dan kenampakan) produk roti manis (10 merek) yang dijual di Kota Malang, menggunakan uji hedonik dan uji rangking.

\section{BAHAN DAN METODE}

\section{Bahan}

Bahan yang digunakan dalam penelitian ini yaitu roti manis yang telah dilakukan cluster random sampling dari 5 kecamatan di Kota Malang. Sampel yang terpilih adalah MYS, NYW, YKA, AMY, MRS, SNT, FPB, SHR, DFL dan HLB.

\section{Metode Penelitian}

Metode penelitian yang digunakan dalam penelitian ini adalah RAK (Rancangan Acak Kelompok) dengan penentuan sampel dengan metode cluster random sampling. Penentuan responden dengan metode purposive sampling yang diperlukan dalam pengisian kuesioner, dimana dalam penelitian ini didapatkan sejumlah 100 responden. Teknik pengambilan data dalam penelitian ini, menggunakan survey yang dilaksanakan pada pengujian organoleptik dengan melakukan uji afektif yang didalamnya terdapat uji hedonik dan uji ranking untuk mengetahui tingkat persepsi konsumen.

\section{HASIL DAN PEMBAHASAN}

\section{Karakteristik Responden}

Hasil karakterisasi responden berdasarkan Jenis Kelamin, Usia, Pekerjaan, Pengeluaran per bulan dan pendidikan terakhir ditampilkan pada Tabel 1. Karakteristik responden berdasarkan jenis kelamin tertinggi adalah wanita sebesar $68 \%$ dan terendah adalah Pria sebesar $32 \%$. Usia responden dikategorikan menjadi 4 kelompok, yaitu 18-21 tahun, 22-25 tahun, 26-35 tahun dan diatas 35 tahun, dimana kelompok terbanyak adalah pada usia 18-21 tahun dengan jumlah persentase sebesar $51 \%$ dan terendah adalah kelompok di atas 35 tahun sebesar 1\%. Karakteristik selanjutnya adalah jenis pekerjaan, dimana persentase tertinggi adalah pelajar sebesar $82 \%$, disusul oleh pekerja swasta sebesar $11 \%$, PNS $6 \%$ dan yang terendah adalah wiraswasta sebesar $1 \%$. Berdasarkan jumlah pengeluaran responden per-bulan, hasil survey menunjukkan bahwa tertinggi pada 1-2 Juta sebesar $45 \%$ dan terendah $>4$ Juta sebesar $2 \%$. Pendidikan Terakhir responden juga bervariasi mulai dari SMP, SMA, Diploma, dan sarjana. Persentase tertinggi pada jenjang SMA sebesar $71 \%$ dan terendah adalah S2/S3 sebesar $1 \%$. 
Tabel 1. Karakteristik responden

\begin{tabular}{ccc}
\hline Karakteristik & Jenis & Jumlah \\
\hline \multirow{2}{*}{ Jenis Kelamin } & Pria & $32 \%$ \\
\cline { 2 - 3 } & Wanita & $68 \%$ \\
\hline \multirow{5}{*}{ Usia } & $18-21$ Tahun & $51 \%$ \\
\cline { 2 - 3 } & 22-25 Tahun & $39 \%$ \\
\cline { 2 - 3 } Pekerjaan & 26-35 Tahun & $9 \%$ \\
\cline { 2 - 3 } & Pelajar & $82 \%$ \\
\cline { 2 - 3 } & PNS & $6 \%$ \\
\cline { 2 - 3 } & Swasta & $11 \%$ \\
\cline { 2 - 3 } & Wiraswasta & $1 \%$ \\
\cline { 2 - 3 } Pengeluaran per-Bulan & Lain-Lain & - \\
\cline { 2 - 3 } & $<1$ Juta & $26 \%$ \\
\cline { 2 - 3 } & $1-2$ Juta & $45 \%$ \\
\cline { 2 - 3 } & $2-3$ Juta & $21 \%$ \\
\cline { 2 - 3 } & $3-4$ Juta & $6 \%$ \\
\cline { 2 - 3 } Pendidikan Terakhir & $>4$ Juta & $2 \%$ \\
\cline { 2 - 3 } & SMP & $1 \%$ \\
\cline { 2 - 3 } & SMA & $71 \%$ \\
\cline { 2 - 3 } & Diploma & $6 \%$ \\
\cline { 2 - 3 } & S1 $1 \%$ \\
\cline { 2 - 3 } & S2/S3 & $1 \%$ \\
\hline
\end{tabular}

\section{Uji Validitas}

Hasil uji validitas dengan menggunakan teknik pearson correlation untuk mengetahui nilai masing masing atribut seperti pada Tabel 2.

Tabel 2. Hasil uji validitas atribut

\begin{tabular}{ccc}
\hline Atribut & $\begin{array}{c}\text { Pearson } \\
\text { Correlation }\end{array}$ & Hasil Uji \\
\hline Warna & 0,555 & Valid \\
\hline Aroma & 0,708 & Valid \\
\hline Kenampakan & 0,514 & Valid \\
\hline Rasa & 0,707 & Valid \\
\hline Tekstur & 0,666 & Valid \\
\hline
\end{tabular}

Dari tabel diatas semua variabel atribut dalam penelitian ini dinyatakan valid, karena nilai pearson correlation > r-tabel diatas 0,3. Menurut Azwar (1999) dalam Priyatno (2010) semua item yang mencapai koefisien korelasi minimal 0,30 daya pembedanya dianggap memuaskan, tetapi apabila jumlah item belum mencukupi maka batas kriteria dapat diturunkan lagi menjadi 0,25. Namun menurunkan batas kriteria dibawah 0,20 sangat tidak disarankan.

\section{Uji Reliabilitas}

Hasil uji reliabilitas dengan menggunakan cronbach's alpha untuk mengetahui item kuesioner dalam penelitian reliabel seperti pada Tabel 3. 
Tabel 3. Hasil uji reliabilitas

\begin{tabular}{ccc}
\hline $\begin{array}{c}\text { Cronbach's } \\
\text { Alpha }\end{array}$ & N of Items & Hasil \\
\hline 0,6265 & 5 & Reliabel \\
\hline
\end{tabular}

Pada hasil uji reliabilitas menunjukkan bahwa semua atribut yang digunakan reliabel karena memiliki nilai cronbach's alpha sebesar 0,6265 untuk semua item kuesioner dan termasuk dalam kategori baik. Hal ini juga berbanding lurus dengan literatur yang mengatakan bahwa, jika nilai alpha > 0,6 artinya reliabilitas mencukupi (sufficient reliability) sementara jika alpha $>0,7$ ini mensugestikan seluruh item reliabel dan seluruh pengujian secara konsisten memiliki reliabilitas yang kuat. Jika alpha $>0,9$ maka reliabilitas dapat dikatakan sempurna (Wahyuni, 2014).

\section{Uji Hedonik}

Dalam pengujian organoleptik pada penelitian ini, diuji dengan menggunakan 5 parameter diantaranya warna, aroma, kenampakan, rasa dan tekstur dengan skala 1-5 untuk persepsi sangat suka hingga sangat tidak suka. Berikut ini adalah hasil dari beberapa uji berdasarkan parameter penelitian.

\section{Warna}

Warna merupakan visualisasi suatu produk yang langsung terlihat lebih dahulu dibandingkan dengan variabel lainnya. Warna secara langsung mempengaruhi persepsi panelis. Hasil Analysis of Variance atribut warna menunjukkan terdapat perbedaan yang signifikan karena F-Hitung lebih besar dari F-Tabel. Selanjutnya dilakukan uji lanjut yaitu uji normalitas yang menunjukkan pada atribut warna tidak terdistribusi normal dengan P-Value dibawah 0,05. Apabila data tidak terdistribusi normal maka dilakukan uji friedman dan dilanjutkan dengan uji perbandingan berganda serta uji BNJ (Beda Nyata Jujur). Hasil dari uji BNJ (Beda Nyata Jujur) seperti pada Tabel 4.

Tabel 4. Hasil Uji BNJ (Beda Nyata Jujur) atribut warna

\begin{tabular}{|c|c|c|c|}
\hline Sampel & $\mathbf{N}$ & Ranks & Grouping \\
\hline MYS & 100 & 288.5 & A \\
\hline NYW & 100 & 502.5 & $B$ \\
\hline YKA & 100 & 509.5 & $B$ \\
\hline AMY & 100 & 515.5 & $B$ \\
\hline MRS & 100 & 552.0 & $B$ \\
\hline SNT & 100 & 569.0 & B \\
\hline FPB & 100 & 572.0 & C D \\
\hline SHR & 100 & 588.5 & $B \quad C \quad D$ \\
\hline DFL & 100 & 693.5 & $C D$ \\
\hline HLB & 100 & 709.0 & D \\
\hline
\end{tabular}

Hasil uji BNJ (Beda Nyata Jujur) menunjukkan MYS paling tidak disukai pada atribut warna dan berbeda nyata dengan semua sampel. Sampel HLB paling disukai pada atribut warna dan tidak berbeda nyata dengan DFL, SHR dan FPB. MYS tidak disukai karena berwarna pucat. Berdasarkan penelitian dari Astuti (2015) tentang Pengaruh Penggunaan Suhu Pengovenan Terhadap Kualitas Roti Manis Dilihat dari Aspek Warna Kulit, Rasa, Aroma dan Tekstur menyebutkan bahwa warna pada kulit adalah warna dari keseluruhan kulit roti manis dari hasil pengovenan. Kulit roti manis yang diharapkan harus memiliki warna coklat keemasan atau golden brown yang rata, serta bebas dari bintik-bintik hitam atau bergaris. Penyebab kulit terlalu pucat antara lain formula kurang lengkap, tepung kurang reaksi, kelebihan ragi, adonan tua, kelembaban dalam proofer box kurang, oven dingin, pembakaran 
kurang waktu. Sedang penyebab warna kulit terlalu coklat tua antara lain terlalu banyak gula, terlalu banyak susu, oven terlalu panas, adonan muda, pembakaran terlalu lama (Overbaking).

\section{Aroma}

Aroma merupakan salah satu variabel kunci, karena pada umumnya cita rasa konsumen terhadap produk makanan sangat ditentukan oleh aroma. Hasil Analysis of Variance atribut aroma menunjukkan terdapat perbedaan yang signifikan karena F-Hitung lebih besar dari F-Tabel. Selanjutnya dilakukan uji lanjut yaitu uji normalitas yang menunjukkan pada atribut aroma terdistribusi normal dengan P-Value diatas 0,05. Apabila data terdistribusi normal maka dilakukan metode tukey pairwise comparisons untuk diperoleh grouping. Hasil dari grouping seperti pada Tabel 5.

Tabel 5. Hasil Uji BNJ (Beda Nyata Jujur) Atribut Aroma

\begin{tabular}{ccccc}
\hline Sampel & $\mathbf{N}$ & Mean & \multicolumn{2}{l}{ Grouping } \\
\hline HLB & 100 & 3.80 & A & \\
\hline MYS & 100 & 3.79 & A & \\
\hline DFL & 100 & 3.41 & A & \\
\hline AMY & 100 & 3.16 & B & \\
\hline FPB & 100 & 3.13 & B & C \\
\hline NYW & 100 & 3.11 & B & C \\
\hline MRS & 100 & 3.05 & B & C \\
\hline SHR & 100 & 3.05 & B & C \\
\hline YKA & 100 & 3.04 & B & C \\
\hline SNT & 100 & 2.95 & & C \\
\hline
\end{tabular}

Hasil grouping menunjukkan SNT paling tidak disukai pada atribut aroma dan berbeda nyata AMY, DFL, MYS dan HLB. Sampel HLB paling disukai pada atribut aroma dan tidak berbeda nyata dengan DFL dan MYS. SNT tidak disukai karena beraroma asam dan tidak beraroma butter. Aroma roti manis yang lebih asam dalam penelitian ini diakibatkan karena lama fermentasi yang digunakan selama proses proofing. Faktor-faktor yang mempengaruhi fermentasi diantaranya adalah suhu, konsentrasi khamir dan $\mathrm{pH}$. Tahapan dalam proses fermentasi adonan adalah dengan asidifikasi dimana selama proses fermentasi selain dihasikan gas $\mathrm{CO}_{2}$ juga dihasilkan asam-asam organik yang menyebabkan penurunan $\mathrm{pH}$ adonan. Karena tingginya kapasitas penyangga (buffer capacity) protein di dalam adonan, maka tingkat keasaman dapat ditentukan dengan menentukan total asam adonan. Proses asidifikasi ini dapat dijadikan indikator bahwa fermentasi adonan berjalan baik. Dengan demikian pengukuran $\mathrm{pH}$ mutlak diperlukan dalam pengendalian proses (Rukmana dan Yuniarsih, 2011)

\section{Rasa}

Rasa menjadi faktor utama penentu konsumen dalam mempertimbangkan dan memilih produk makanan yang akan dikonsumsi. Hasil Analysis of Variance atribut rasa menunjukkan terdapat perbedaan yang signifikan karena F-Hitung lebih besar dari F-Tabel. Selanjutnya dilakukan uji lanjut yaitu uji normalitas yang menunjukkan pada atribut rasa terdistribusi normal dengan P-Value diatas 0,05. Apabila data terdistribusi normal maka dilakukan metode tukey pairwise comparisons untuk diperoleh grouping. Hasil dari grouping seperti pada Tabel 6.

Hasil grouping menunjukkan SHR paling tidak disukai pada atribut rasa dan berbeda nyata dengan semua sampel. Sampel MRS paling disukai pada atribut aroma dan tidak berbeda nyata dengan DFL, HLB, YKA dan MYS. Rasa asam pada SHR yang menyebabkan tidak disukai panelis. Proses produksi flavor dimana terbentuknya alkohol, penurunan $\mathrm{pH}$, dan terbentuknya metabolit lainnya secara langsung akan berperan sebagai prekursor flavor dan 
rasa roti. Akibat proses fermentasi tersebut dapat menghasilkan roti dengan mutu organoleptik yang tinggi (Fairuz, 2014).

Tabel 6. Hasil Uji BNJ (Beda Nyata Jujur) Atribut Rasa

\begin{tabular}{cccc}
\hline Sampel & $\mathbf{N}$ & Mean & \multicolumn{2}{c}{ Grouping } \\
\hline MRS & 100 & 3.80 & A \\
\hline MYS & 100 & 3.63 & A B \\
\hline HLB & 100 & 3.59 & A B \\
\hline YKA & 100 & 3.55 & A B C \\
\hline DFL & 100 & 3.39 & A B C \\
\hline FPB & 100 & 3.31 & B C D \\
\hline SNT & 100 & 3.24 & B C D \\
\hline AMY & 100 & 3.14 & C D \\
\hline NYW & 100 & 2.96 & D E \\
\hline SHR & 100 & 2.69 & \\
\hline
\end{tabular}

\section{Tekstur}

Tekstur masih dipertimbangkan oleh beberapa konsumen dalam menentukan mana yang akan dikonsumsi. Hasil Analysis of Variance atribut tekstur menunjukkan terdapat perbedaan yang signifikan karena F-Hitung lebih besar dari F-Tabel. Selanjutnya dilakukan uji lanjut yaitu uji normalitas yang menunjukkan pada atribut tekstur tidak terdistribusi normal dengan P-Value dibawah 0,05. Apabila data tidak terdistribusi normal maka dilakukan uji friedman dan dilanjutkan dengan uji perbandingan berganda serta uji BNJ (Beda Nyata Jujur). Hasil dari uji BNJ (Beda Nyata Jujur) seperti pada Tabel 7.

Tabel 7. Hasil Uji BNJ (Beda Nyata Jujur) Atribut Tekstur

\begin{tabular}{|c|c|c|c|c|c|}
\hline Sampel & $\mathbf{N}$ & Mean & \multicolumn{3}{|c|}{ Grouping } \\
\hline DFL & 100 & 667.0 & & & $\mathrm{D}$ \\
\hline MRS & 100 & 639.0 & & C & $\mathrm{D}$ \\
\hline YKA & 100 & 613.5 & & C & $D$ \\
\hline HLB & 100 & 613.5 & & C & D \\
\hline FPB & 100 & 589.0 & & C & $D$ \\
\hline MYS & 100 & 576.0 & $B$ & C & $\mathrm{D}$ \\
\hline SNT & 100 & 524.0 & B & C & \\
\hline AMY & 100 & 511.5 & $B$ & C & \\
\hline NYW & 100 & 439.0 & $A B$ & & \\
\hline SHR & 100 & 327.5 & A & & \\
\hline
\end{tabular}

Hasil grouping menunjukkan SHR paling tidak disukai pada atribut tekstur dan berbeda nyata dengan semua sampel. Sampel DFL paling disukai pada atribut aroma dan tidak berbeda nyata dengan MRS, YKA, HLB, FPB dan MYS. Tekstur pada SHR yang keras diakibatkan adanya gluten. Ketika tepung dicampur dengan air, gluten akan membentuk massa viskoelastisitas yang mengikat semua bahan adonan terutama pati menjadi suatu jaringan. Lapisan film yang terbentuk bersifat impermeabel terhadap gas, sehingga dapat memerangkap gas dan membentuk pori. Selanjutnya pada saat proses pemanggangan (baking) terjadi gelatinisasi pati dan koagulasi gluten yang dapat membentuk crumb dan tekstur yang lembut (Fairuz, 2014).

\section{Kenampakan}

Kenampakan juga menjadi salah satu faktor yang dipertimbangkan bagi konsumen ketika akan membeli makanan ataupun produk barang dan jasa. Hasil Analysis of Variance atribut kenampakan menunjukkan terdapat perbedaan yang signifikan karena F-Hitung lebih besar dari F-Tabel. Selanjutnya dilakukan uji lanjut yaitu uji normalitas yang menunjukkan pada atribut kenampakan terdistribusi normal dengan P-Value diatas 0,05. Apabila data 
terdistribusi normal maka dilakukan metode tukey pairwise comparisons untuk diperoleh grouping. Hasil dari grouping seperti pada Tabel 8.

Tabel 8. Hasil Uji BNJ (Beda Nyata Jujur) Atribut Kenampakan

\begin{tabular}{cccll}
\hline Sampel & $\mathbf{N}$ & Mean & \multicolumn{2}{l}{ Grouping } \\
\hline HLB & 100 & 3.85 & A & \\
\hline DFL & 100 & 3.84 & A B & \\
\hline SHR & 100 & 3.54 & A B & C \\
\hline SNT & 100 & 3.50 & A B & C \\
\hline FPB & 100 & 3.45 & A B & C \\
\hline AMY & 100 & 3.44 & B & C \\
\hline YKA & 100 & 3.40 & & C \\
\hline NYW & 100 & 3.40 & & C \\
\hline MRS & 100 & 3.17 & & C \\
\hline MYS & 100 & 2.60 & & \multicolumn{2}{c}{ D } \\
\hline
\end{tabular}

Hasil grouping menunjukkan MYS paling tidak disukai pada atribut kenampakan dan berbeda nyata dengan semua sampel. Sampel HLB paling disukai pada atribut kenampakan dan tidak berbeda nyata dengan DFL, SHR, SNT dan FPB. Kenampakan yang kurang menarik pada SHR yang menyebabkan tidak disukai panelis. Kenampakan merupakan parameter yang dapat dilihat pada kue secara visual yang menyebabkan panelis tertarik dan suka produk tersebut. Kenampakan suatu produk makanan merupakan faktor penarik utama sebelum panelis menyukai sifat mutu sensoris lainnya seperti rasa, aroma, warna dan tekstur. Pada umumnya konsumen memilih makanan yang memiliki kenampakan menarik (Thalib, 2005).

\section{Uji Ranking}

Menurut Wahono (2006), uji rangking digunakan untuk mengetahui perbedaan intensitas sifat pada suatu set sampel. Dalam uji ranking panelis diminta untuk mengurutkan secara menurun atau menaik dengan nilai 1 - 10 berdasarkan urutan tingkat kesukaan (ranking). Panelis diminta untuk memberikan peringkat 1 apabila sangat suka hingga peringkat 10 apabila sangat tidak suka berdasarkan parameter uji. Pada hasil uji yang menunjukkan semakin kecil skornya maka sampel tersebut mendapat peringkat 1 dan paling baik karena banyak mendapatkan peringkat 1-5, demikian pula sebaliknya. Hasil uji rangking seperti pada Tabel 9.

Tabel 9. Hasil uji ranking

\begin{tabular}{|c|c|c|c|c|c|c|c|}
\hline \multirow[t]{2}{*}{ RANK } & \multirow[t]{2}{*}{ OUTLET } & \multicolumn{5}{|c|}{ TOTAL SKOR ATRIBUT } & \multirow[t]{2}{*}{ TOTAL } \\
\hline & & WARNA & AROMA & KENAMPAKAN & RASA & TEKSTUR & \\
\hline 1 & HLB & 385 & 302 & 375 & 390 & 449 & 1901 \\
\hline 2 & DFL & 314 & 481 & 356 & 462 & 427 & 2040 \\
\hline 3 & FPB & 459 & 504 & 419 & 459 & 442 & 2283 \\
\hline 4 & YKA & 553 & 548 & 520 & 442 & 496 & 2559 \\
\hline 5 & AMY & 518 & 516 & 511 & 560 & 515 & 2620 \\
\hline 6 & SNT & 502 & 616 & 502 & 573 & 541 & 2734 \\
\hline 7 & MRS & 584 & 568 & 704 & 494 & 517 & 2867 \\
\hline 8 & SHR & 512 & 603 & 470 & 684 & 650 & 2919 \\
\hline 9 & MYS & 778 & 443 & 743 & 458 & 526 & 2948 \\
\hline 10 & NYW & 565 & 589 & 570 & 648 & 607 & 2979 \\
\hline
\end{tabular}

Hasil menunjukkan bahwa secara umum, sampel HLB menunjukkan bahwa kualitas roti manis dari semua atribut dinilai sangat baik sehingga memperoleh peringkat pertama dengan total akhir sebesar 1901. Pada peringkat akhir yang paling tinggi adalah NYW dengan 
total akhir sebesar 2979. Uji ranking ini bisa mengukur pengaruh proses terhadap mutu produk. Dengan menggunakan uji ranking maka mutu produk dapat diketahui dan diurutkan. Nilai hasil uji ranking yang dilakukan hanyalah nomor urut, tidak menyatakan besaran skalar.

\section{SIMPULAN}

Dari hasil penelitian yang telah dilakukan dapat ditarik kesimpulan yaitu pengujian sifat fisik dan organoleptik menghasilkan data pada atribut warna sampel MYS berbeda nyata dengan sampel HLB. Sebaliknya pada sampel HLB tidak berbeda nyata dengan DFL. Atribut aroma SNT berbeda nyata dengan sampel HLB. Sebaliknya. sampel HLB tidak berbeda nyata dengan MYS. Atribut kenampakan. sampel MYS berbeda nyata dengan sembilan sampel yang lain dan sebaliknya sampel HLB tidak berbeda nyata dengan DFL. Atribut rasa sampel SHR tidak berbeda nyata dengan sampel NYB namun berbeda nyata dengan sampel MRS. Atribut tekstur didapatkan hasil SHR tidak berbeda nyata dengan sampel NYB namun berbeda nyata dengan sampel DFL. Hasil Uji Rangking menunjukkan bahwa proti manis HLB menduduki peringkat 1 sedangkan NYW menduduki peringkat 10 untuk keseluruhan nilai kesukaan.

\section{DAFTAR PUSTAKA}

Astuti, R Mijling. 2015. Pengaruh Penggunaan Suhu Pengovenan Terhadap Kualitas Roti Manis Dilihat Dari Aspek Warna, Kulit, Rasa, Aroma dan Tekstur. Jurnal Teknobuga Vol 2 No. 22

Badan Pusat Statistik Republik Indonesia. 2015. Data Ekonomi dan Perdagangan. dilihat pada 18 Agustus 2017. http://www.bps.go.id//

Dinas Perindustrian dan Perdagangan Provinsi Jawa Timur. 2017. Data Perkembangan dan Pembangunan UKM dan UMKM. dilihat pada 18 Agustus 2017. http://disperindag.jatimprov.go.id/.

Priyatno. 2010. Power Branding Membangun Merek Unggul dan Organisasi Pendukungnya. Mizan Publika. Jakarta. Hal : 67

Rauf, Rusdin. 2015. Daya Serap Air Sebagai Acuan Untuk Menentukan Volume Air Dalam Pembuatan Adonan Roti Dari Campuran Tepung Terigu dan Tepung Singkong. Agritech, Vol 35 No 3: 324-330.

Rukmana dan Yuniarsih. 2001. Cara Pembuata Roti . Yogyakarta: Kanisius.

Thalib, A. 2005. Daya Terima Panelis Terhadap Brownies Panggang Berbahan Baku Tepung Umbi Daluga (Cyrtospermamerkussi (Hassk) (Schott). Skripsi. Universitas Sam Ratulangi. Manado.

Wahono, T. 2006. Dasar-dasar Uji Indrawi. Jurusan Teknologi Hasil Pertanian UB. Malang.

Wahyuni, Sri. 2017. Analisis Hasil Organoleptik Hasil Perbaikan Tekstur Roti Manis Wikau Maombo Dengan Aplikasi Xantan Gum. Jurnal Sains dan Teknologi Pangan Vol 2 (4) : $736-748$

Wisesa, Taufik. 2014. Penentuan Nilai maksimum Proses Ekstraksi Buah Naga Merah (Hylocereus polyrhizus). Jurnal Pangan dan Agroindustri. Vol 2 (3) : 88 -_97 